Research Article

\title{
Cognitive Acceleration through Science Education (CASE) program: Accelerating students' cognitive development
}

Chandra Adi Prabowo a,1,*, Wahyu Widodo a,2

a Department of Biology Education, Faculty of Education, Universitas Tribhuwana Tunggadewi, Telaga Warna Street Tlogomas Lowokwaru, Malang, East Java 65144, Indonesia

${ }^{1}$ chandradipra@rocketmail.com ${ }^{*}$; ${ }^{2}$ wahyuwidodo@gmail.com

${ }^{*}$ Corresponding author

\begin{tabular}{|c|c|}
\hline ARTICLE INFO & ABSTRACT \\
\hline $\begin{array}{l}\text { Article history } \\
\text { Received November 13, } 2018 \\
\text { Revised June 28, } 2019 \\
\text { Accepted July 08, } 2019 \\
\text { Published July 16, } 2019 \\
\text { Keywords } \\
\text { CASE program } \\
\text { Cognitive development } \\
\text { Scientific reasoning skill task }\end{array}$ & 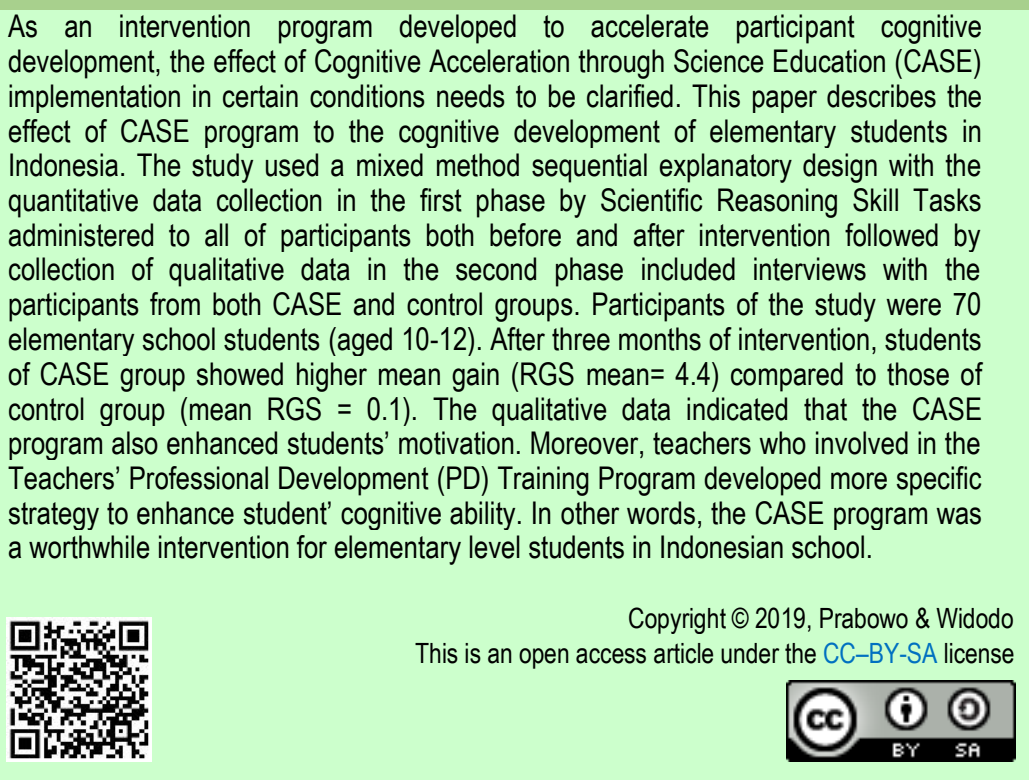 \\
\hline
\end{tabular}

\section{INTRODUCTION}

Cognitive Acceleration through Science Education (CASE) Program, founded by Adey, Shayer \& Yates at King's College London in the early 1980's is the two years intervention program came in responding the problem in science education around the world (Venville \& Oliver, 2015). A previous research showed that secondary school science curricula, which contain complex scientific concepts and abstract models in many nations, generally exceeded students' capabilities to study because students require to use what Piaget called formal operational thinking (Adeyemo, 2010). On other hand, this type of thinking is essential for students to master scientific reasoning skills such as identifying problems, formulating a hypothesis, designing scientific experiments, and making conclusion based on the research findings. Thus, the main purpose of CASE 
program was to enhance the proportion of students who possess formal operational thinking abilities (Corno, 2015).

The theoretical foundation of CASE program was Piaget cognitive development theory. Piaget described that formal operational thinking is characterized by the ability to handle more than one variable in mind at once. For example, to weigh up two sides of an opinion, to determine the advantages and disadvantages of a particular action, or to be able to see the effect of a number of input variables (e.g. number of proteins, carbohydrate, fat) on an outcome (the mass of muscle). However, Piaget suggested that this level of thinking will be achieved when children reach around 14 or 15 years. Cognitive acceleration means the process of accelerating students' 'natural' development process by presenting an intervention program to enhance students' level of thinking especially in science (Milar, Venville, \& Oliver, 2014).

Scientific thinking is described as the representation of general intelligence. The example of scientific thinking development is children who are doing their practical task during an investigation such as ordering things by their mass, exploring conservation, analyzing cause and effect, and controlling variables (Inhelder \& Piaget, 1958). Piaget drew conclusion about how to measure children's cognitive development by their performance in these apparently scientific tasks. The example of non-verbal tests on general intelligence is Raven's Matrices, while Calvert non-verbal test is the other way to measure children's cognitive development. These tests tap into children's ability to use their deductive and inductive reasoning which is fundamental of scientific thinking (Finau, Treagust, Won, \& Chandrasegaran, 2018).

The correlation between scientific thinking and general thinking was supported by some empirical findings. Although Piaget expressed stages of cognitive development in scientific terms, however, the description of cognitive development stages such as abstract reasoning or concrete operations are generally acceptable in all forms of learning. Thus, early childhood experiences are crucial for (Gopnik, 2012). This finding shows the intimate link between scientific thinking and general thinking.

Overall, many researches showed that CASE program was effective to accelerate cognitive development of participant. However, there have been limited studies concerned on the effect of cultural factors to the success of the program. Therefore, this research intended to investigate how does the different culture of education affect the result of CASE program in outside of England where the program was developed. The objective of this research was to investigate the effect of CASE program to cognitive development of elementary students in Indonesia.

\section{METHOD}

\section{Research Design}

The study used a mixed method sequential explanatory design consist of two stages of data collection. During the first stage, the quantitative data were collected using quasi-experimental design followed by the collection and analysis of the qualitative data in the second stage (Creswell, 2012). This study integrated the strength of both the quantitative and qualitative data. Participants were 70 students of fifth grade of elementary school (age 10-12) which were separated in two groups (45 students for each).

Scientific Reasoning Task (SRT) was used to assess the participants' cognitive development both in pretest and post-test of this study. To assess the effectiveness of the CASE program, the Students' Adaptive Learning Engagement (SALE) questionnaire as pre- and post-survey followed by semi structured reflective interview were employed to reveal the students' and teacher's perspectives and experiences after participating the CASE program.

\section{Teacher Professional Development (PD) Training Program}

Teacher Professional Development (PD) training program was conducted during the study. Teacher learnt about teaching plans and strategies of CASE as they hold an important role in this program. The program was separated in six sessions based on the work of (Adey, 2003) as shown in Table 1.

In each PD training session, teacher discussed and shared their experiences during the CASE lesson. The purpose of the sharing session was to improve their teaching in the next activity. A volunteer had an opportunity to teach for one CASE activity during the training while others observed for later discussion and feedback.

\section{Instruction in the CASE Group}

The CASE intervention used in this study was basically similar to the original CASE program adapted and modified from Thinking Science (Adey, 2003). However, due to the limited time for this study, the intervention was reduced only for 8 lessons and were delivered over 4 months (July - October 2018). The intervention was given every two weeks to replace the ordinary science lesson. Each lesson of CASE focused on developing 
specific reasoning patterns such as controlling variables, ratio and proportionality, probability and correlation, and also the use of abstract models to explain and predict.

In the first phase, the activity was called 'concrete preparation' where the context of the activity was introduction to the students. Teacher's role was to record student's expression and suggestion of the best way can be done to achieve the learning goals. Teacher also asked questions which helped students to understand what they should do in the next phase.

The second phase of the activity was 'cognitive conflict' which is the central of the CASE activity. Several problems were presented to the students in which the purpose was to challenge their prior knowledge and personal hypothesis. In this case, the teacher's role was observing each group as they were working and encouraging students to focus on the problems based on their own perspectives.

The next phase was 'social construction'. In this part, students worked collaboratively in groups in which there were about four people who were trying to resolve the cognitive conflict. The results obtained from the students' work session of each group were then shared to the class (for at least ten minutes). In this phase, each group reported to the whole class members about their findings. In addition, students or groups could express their difficulties to the whole class member, allowing the other groups to contribute by generating the best solution from the discussion.

Table 1. Teachers professional development (PD) training program curricula

\begin{tabular}{|c|c|}
\hline Activity & Materials \\
\hline Session 1 & Foreword of the whole program \\
\hline \multirow[t]{4}{*}{ Session 2} & 1. Sharing the data on the type of thinking available in the key stage 3 population; \\
\hline & $\begin{array}{l}\text { 2. Getting a sense of the sort of thinking demanded by the science curriculum, and so bring home the problem } \\
\text { that there is a gap between students' thinking and curriculum demands; }\end{array}$ \\
\hline & 3. Introducing an approach to overcome problem; and \\
\hline & 4. Making the concrete with the next few CASE activities \\
\hline \multirow[t]{4}{*}{ Session 3} & 1. Checking the students' progress in their activities, providing opportunity for sharing experiences; \\
\hline & $\begin{array}{l}\text { 2. Going into more detail of the nature of formal operational thinking, and showing how it is necessary for higher } \\
\text { levels in science curriculum; }\end{array}$ \\
\hline & 3. Focusing on the process of social construction; and \\
\hline & 4. Going over the next few activities to be taught \\
\hline \multirow[t]{3}{*}{ Session 4} & 1. Giving participants an opportunity for feedback on activities taught so far. \\
\hline & 2. Giving an introduction of metacognition concept. \\
\hline & 3. Introducing the next set of activities to be taught \\
\hline Session 5 & $\begin{array}{l}\text { 1. Giving participants an opportunity to practice in recognizing the pillars in lesson transcripts, and } \\
\text { 2. Considering the power of peer observation. }\end{array}$ \\
\hline \multirow[t]{3}{*}{ Session 6} & 1. Reflecting on coaching in which the participants have experienced, \\
\hline & 2. Taking an overview of the development of thinking throughout the CASE activities, and \\
\hline & 3. Giving some thoughts in making CASE as an integrated part of the school science curriculum \\
\hline
\end{tabular}

Metacognition follows where the students are encouraged to reflect on their thinking and explain their thoughts to each other as they solve problems or perform tasks. Teachers play an important role in this process by asking the students various questions which express their ideas. In the other words, it is re-establishing of equilibrium.

The last phase was 'bridging'. This was the part of the class where the teacher assisted students in applying their new thinking into different-but-relevant contexts. Bridging is regarded as a powerful teaching strategy, where students are encouraged to keep practicing and challenging the new thinking developed long after the lesson, they first learned in was over.

\section{Instruction in Control Group}

The control group of this study was instructed using teaching strategies which normally used in their classroom. The teaching strategies tended to teacher centered learning because their teaching practices mainly using teacher presentation and writing notes. Teacher preferred this strategy to complete the administration of syllabus because there were a lot of materials which must be delivered in limited time.

\section{Data Collection}

The quantitative data about the effect of the CASE program were assessed using Science Reasoning Tasks (SRT's) developed by the team of "Concepts in Secondary Mathematics and Science" at Chelsea College, University of London (Adey, 2003). These tasks measured the students' ability to use Concrete and Formal thinking strategies. The key characteristics of the tasks used in this study can in be seen in Table 2. 
The SRT's were administered to both CASE group and control group before and after the intervention to investigate the effects of CASE program to students' cognitive development. The items that were used in the SRT's were mostly different in the pre-test and post-test but addressed the same level (2B-3B).

Table 2. Features of Science Reasoning Tasks (SRT's)

\begin{tabular}{|c|c|c|c|c|c|}
\hline & No. & Name & Content & Range & No. of items \\
\hline Pre-test & II & $\begin{array}{l}\text { Volume and } \\
\text { Heaviness }\end{array}$ & $\begin{array}{l}\text { A global concept of 'size' in terms of mass, } \\
\text { weight, volume and density }\end{array}$ & 2B-3B & 14 \\
\hline Post-test & IV & $\begin{array}{l}\text { Equilibrium in the } \\
\text { balance }\end{array}$ & $\begin{array}{l}\text { Investigating the pupil's ability to recognize and } \\
\text { use inverse proportions in a simple beam balance }\end{array}$ & $2 \mathrm{~B}-3 \mathrm{~B}$ & 13 \\
\hline
\end{tabular}

The qualitative data in this study were collected using Students' Adaptive Learning Engagement (SALE) and semi structured reflective interview. The SALE questionnaire adapted from Velayutham. Aldridge, and Fraser (2011) were administered to both groups in pre-test and post-test. The SALE instrument consisted of four aspects: learning goal orientation, task value, self-efficacy and self-regulation. Learning goal orientation, task value and self-efficacy were the three components of motivation which were consistently associated with students' adaptive motivational beliefs (Schunk \& Zimmerman, 2008), each of these components is related to the successful engagement in self-regulated learning. The example of items for each SALE aspects are shown in Table 3.

Table 3. Students' Adaptive Learning Engagement (SALE) sample items

\begin{tabular}{|c|c|}
\hline Aspects & Sample Items \\
\hline \multirow{3}{*}{ Learning goal orientation } & 1. One of my goals is to learn new science contents. \\
\hline & 2. One of my goals is to learn as much as I can. \\
\hline & 3. It is important for me to improve my scientific reasoning skills. \\
\hline \multirow{3}{*}{ Task value } & 1. What I learn is relevant to me. \\
\hline & 2. What I learn is of practical value. \\
\hline & 3. What I learn encourages me to think. \\
\hline \multirow{3}{*}{ Self-efficacy } & 1. I can figure out how to do difficult work. \\
\hline & 2. Even if the science work is hard, I can learn it. \\
\hline & 3. I can understand the contents taught. \\
\hline \multirow{3}{*}{ Self-regulation } & 1. Even when the tasks are uninteresting, I keep working. \\
\hline & 2. I do not give up even when the work is difficult. \\
\hline & 3. I keep working until I finish what I am supposed to do. \\
\hline
\end{tabular}

All of instruments in this study were adapted and translated into Bahasa Indonesia to accommodate participants' language. Instrument adaptation process in this study was based on Beaton, Bombardier, Guillemin, and Ferraz (2000) that consisted of initial translation, synthesis of the translation, back translation, expert committee, and pretesting. Prior to the intervention, the adapted CASE and SALE instruments (the both English and Bahasa Indonesia versions) were piloted and tested to 30 elementary students from two elementary schools in Malang. The purpose of this pilot study was to check the clarity and suitability of the items and to eliminate ambiguities in the wording of the items.

Semi-structured interviews were conducted to 5 students of the CASE group and 4 students of the control group. The purpose the interviews in this study was to get more in-depth information on the perceptions of the students about CASE intervention. All student interviews were audio-recorded and fully transcribed. The analysis of the interview was through repeated reading of the transcripts as well as repeated listening to the recorded audio to identify the ideas that were relevant to research questions and to provide insight into the quantitative data (Creswell, 2012).

\section{Data analysis}

The data obtained from pre and post-test were then analyzed using Residual Gain Score (RGS). Meanwhile the differences of students' motivation and regulation were determined using t-test which were completed using Cohen's d (J. Cohen, 1988; L. Cohen, Manion, \& Morrison, 2007).

\section{RESULTS AND DISCUSSION}

\section{Students Performance on SRT}

The total of 70 students completed SRT both on pre-test and post-test in which the 35 students were part of CASE group and the rest were the part of control group. The average of students' age when we conducted the study was 11.6 years old. 
The initial analysis results (Table 4) showed that the mean value of pre-test of CASE group (4.7) was higher compared to the control group 3.7. This is in line with the post-test results, in which the CASE group reached the mean value as high as 8.3 while the control group only achieved 4.7

In order to explore greater insight into the results, the scores achieved from pretest and post-test of the both control and experimental groups were analyzed using Residual Gain Score (RGS) analysis. This technique works by using the pre-test score of each student as a covariate to his/her post-test score which then a regression line was constructed by computing those scores for the pre- and post- test scatter. The pre-test scores of each CASE group student were then entered into the regression equation. Thus, the difference between the predicted (the calculation is not served in this paper) and actual post-test score estimated the effect of the CASE based intervention in comparison with the control group. Table 4 shows the pre- and posttest mean scores and the gains formed by each group.

Table 4 describes that the residual gain scores for CASE group (4.4) were greater compared to the control group (0.1). These results show that the actual score gained (8.3) by the experimental group got was over the predicted score (the calculation is not served in this paper) compared to the control group results. The RGS mean value of the control group (0.1) implies that this group scored as the prediction even though no greater than the expectation (the calculation is not served in this paper). The results suggest that the CASE program was successful in improving students' cognitive ability in science.

Table 4. RGS mean values for CASE and control group

\begin{tabular}{ccccc}
\hline Group & N & Pre-test mean & Post-test mean & RGS mean \\
\hline CASE & 35 & 4.2 & 8.3 & 4.4 \\
Control & 35 & 3.7 & 4.7 & 0.1 \\
\hline
\end{tabular}

The findings from this study were consistent with prior research findings that the explicit teaching of CASE was beneficial for students who participated in the intervention (Adey, Robertson, \& Venville, 2002). Students' performance on SRT indicated that students in the CASE group made significant cognitive gains over the four months of the intervention. This in line with Amineh and Asl (2015) who concluded that cognitive growth will firstly occur in social level which then followed by the individual level. The overall results indicate that the CASE intervention with its teacher professional development training program and classroom activities was successful.

The students who participated in the CASE intervention were found to show more positive attitudes toward lesson compared to those from the control group. These findings suggest positive associations between learning attitudes (shown in Table 5 and Table 6) and academic achievement (shown in Table 4). This finding is consistent with other studies conducted by Velayutham et al. (2011) and Wolters (1999) who argued that motivation and self-regulation-based learning have a positive relationship with academic achievement.

\section{Students' Motivation and Regulation}

According to the SALE analysis results of pre- and post-test scores, there were significant differences between the pre-test and post-test mean scores of the four aspects of the SALE instrument for students in the CASE group (see Table 5). The post-test mean scores of the four aspects were significantly higher than the pre-test mean values. These results suggest that the CASE program was effective in improving the students' motivation and self-regulation levels.

Table 5. SALE pre and post-test results in CASE group

\begin{tabular}{lcccccc}
\hline \multirow{2}{*}{ Aspects of SALE } & \multicolumn{2}{c}{ Pre-test } & \multicolumn{2}{c}{ Post-test } & \multirow{2}{*}{ value } & \multirow{2}{*}{ Effect size (Cohen's $\boldsymbol{d}$ ) } \\
\cline { 2 - 5 } & Mean & SD & Mean & SD & & .47 \\
Learning goal orientation & 4.26 & .67 & 4.53 & .47 & $5.70^{*}$ & .66 \\
Task value & 2.04 & .77 & 4.46 & .46 & $7.81^{*}$ & .58 \\
Self-efficacy & 3.93 & .81 & 4.32 & .51 & $6.30^{*}$ & .70 \\
Self-regulation & 4.00 & .74 & 4.42 & .44 & $7.86^{*}$ &. \\
\hline
\end{tabular}

Reversely, there were no significant difference between pre- and post-test scores among students in the control group. The post-test mean scores for three aspects were lower than the pre-test mean scores while learning goal orientation had a slight (insignificant) increase in the post-test scores (see Table 6). The results show that the traditional instructional program that was used in the control group had no significant effect in students' motivational and self-regulation levels.

There are several factors interfering students' motivation and regulation. These factors can be the teacher's role (Shaikh \& Khoja, 2012) and attitude (Oroujlou \& Vahedi, 2011), gender (Eshun, 2004; Osagie \& Alutu, 
2016), the approach (Chao, Chen, \& Chuang, 2014) learning model employed by teacher (Wyk, 2017), teacher-student interaction (Bashir, Bajwa, \& Rana, 2014), and so forth. The better the understanding of these factors, the better the teaching preparation as well as learning processes management conducted by the all parties, particularly teachers as well as schools in term of the system provided by school (e.g. facilities for the both teachers and students, training for teachers to improve their competencies, etc.).

Table 6. SALE pre and post-test results in control group

\begin{tabular}{lcccccc}
\hline \multirow{2}{*}{ Aspects of SALE } & \multicolumn{2}{c}{ Pre-test } & \multicolumn{2}{c}{ Post-test } & \multirow{2}{*}{ value } & \multirow{2}{*}{ Effect size (Cohen's $\boldsymbol{d}$ ) } \\
\cline { 2 - 5 } & Mean & SD & Mean & SD & & .76 \\
Learning goal orientation & 4.40 & .69 & 4.42 & .59 & .31 & .66 \\
Task value & 4.35 & .71 & 4.31 & .64 & -.44 & .14 \\
Self-efficacy & 4.33 & .62 & 4.21 & .63 & -1.47 & .12 \\
Self-regulation & 4.35 & .56 & 4.24 & .56 & -1.55 &. \\
\hline
\end{tabular}

\section{Students' Interview Responses}

Five students from CASE group were interviewed regarding their participation in the program. Most of these students (more than $80 \%$ ) mentioned that they enjoyed the CASE activities and their teacher's support that they had received. The students noted that the CASE program positively influenced their learning experience and interaction with the teachers. They also mentioned the changes in their learning attitudes such as selfdetermination, confidence, self-regulation and desire for success. Moreover, four students of the control group were interviewed with regards to their learning of the traditional science instruction, and also reflect on the teaching strategies of their teachers. Their responses were very important to improve their teacher's instruction strategies.

Overall, the interview data seem to support the findings from the quantitative data. In the interviews done, the CASE group students revealed that they gained more positive attitudes towards their learning science which led to the better engagement in their motivation and achievement.

The interview findings indicated that the implementation of the CASE program was comprehensive and well-supported by teachers who attended professional development. A number of challenges were faced by the teachers including combining the program into a crowded curriculum, organizing the program, and arranging the students to accommodate the group work for social construction.

The 8 selected lesson activities were implemented to give rise to classroom work focused directly within the five 'reasoning pattern'. Cognitive conflict enhanced the discussion, while metacognition and problem solving encourage students to work together on the lesson activities (Finau, et al., 2016). For the CASE lessons, the role of the teacher shifted from a director to a facilitator of learning activities. During the group discussions, the teacher encouraged students to think the ideas that came from their earlier discussions. It is reported that not only student's attitude determines the learning effectiveness, but also teacher's (Oroujlou \& Vahedi, 2011). In this case, teachers were not required to provide all answers for students' questions but to facilitate and encourage students to explore together the possible solutions by giving tasks.

With the results that have been obtained in this study, it can speculate that the keys to success of the CASE program in Indonesian classrooms are the cognitive conflicts set with specific reasoning patterns for each lesson, the pedagogy that encourage the group or whole class discussion and metacognition. These instructional strategies have the capacity to improve the reasoning ability of the students which leads to the better performance.

As mentioned earlier, the goal of this CASE program was to develop formal operational thinking in term of higher-order thinking (Mccormack, Finlayson, \& Mccloughlin, 2009) by improving students' academic performance in science regardless of their maturation. The findings of this study show that the CASE intervention program has improved students' cognitive ability which led to the improvement of their academic achievement as well as their learning attitudes by being self-regulated and motivated.

\section{CONCLUSION}

Overall, the CASE program has set out what it planned to achieve. The results showed that the RGS of the CASE group was higher than the control group. This approach involved teachers focusing on thinking skills rather than content knowledge and there was a demand for the student to be engaged and think. The further effects of this program were that the students' contributions in CASE program have made them performed better in motivation and self-regulation. 


\section{REFERENCES}

Adey, P. (2003). Thinking science professional edition. Oxford: OUP Oxford. Retrieved from https://www.abe books.com/9780748773817/Thinking-Science-Professional-Edition-CD-ROM-0748773819/plp

Adey, P., Robertson, A., \& Venville, G. (2002). Effects of a cognitive acceleration programme on Year 1 pupils. British Journal of Education Psychology, 72, 1-25. Retrieved from http://www.ingentacon nect.com/content/bpsoc/bjep/2002/00000072/00000001/art00001

Adeyemo, S. A. (2010). Students' Ability Level and Their Competence in Problem-Solving Task in Physics. International Journal of Educational Research and Technology, 1(2), 35-47. Retrieved from http://www. soeagra.com/ijert/vol2/7.pdf

Amineh, R. J., \& Asl, D. H. (2015). Review of constructivism and social constructivism. Journal of Social Sciences, Literature and Languages, 1(1), 9-16. Retrieved from https://pdfs.semanticscholar.org/3890 /3f4a7255496f75124d639e14e9b810c17370.pdf

Bashir, S., Bajwa, M., \& Rana, S. (2014). Teacher as a role model and its impact on the life of female students. International Journal of Research-Granthaalayah, 1(1), 9-20. Retrieved from http://granthaala yah.com/Vol1lss1.html

Beaton, D. E., Bombardier, C., Guillemin, F., \& Ferraz, M. B. (2000). Guidelies for the process of crosscultural adaptation of self-report measures. SPINE, 25(24), 3186-3191. doi: https://doi.org/10.1080/000 163599428823

Chao, C., Chen, Y., \& Chuang, K. (2014). Exploring students ' learning attitude and achievement in flipped learning supported computer aided design curriculum: A study in high school engineering education. Wiley Periodicals, 514-526. doi: https://doi.org/10.1002/cae.21622

Cohen, J. (1988). Statistical power analysis for the behavioral sciences second edition (second). New York: Lawrence Erlbaum Associates, Publishers. Retrieved from http://www.utstat.toronto.edu/ brunner/ oldclass/378f16/readings/CohenPower.pdf

Cohen, L., Manion, L., \& Morrison, K. (2007). Research methods in education (Sixth Edit). London and Newyork: Routledge. Retrieved from http://gtu.ge/Agro-Lib/RESEARCH METHOD COHEN ok.pdf

Corno, L. (2015). Handbook of Educational Psychology. New York: Routledge. Retrieved from https://play. google.com/books/reader?id=KPAsCgAAQBAJ\&printsec=frontcover\&source=gbs_atb\&pg=GBS.PP1

Creswell, J. W. (2012). Educational research planning, conducting, and evaluating quantitative and qualitative research. (Paul A. Smith; Christina Robb; Matthew Buchhholtz, Ed.) (Fourth Edition). Boston: Pearson. Retrieved from http://basu.nahad.ir/uploads/creswell.pdf

Eshun, B. A. (2004). Sex-differeces in attitude of students towards Mathematics in secondary schools. Mathematics Connection, 4, 1-14. doi: https://doi.org/10.4314/mc.v4i1.21498

Finau, T., Treagust, D. F., Won, M., \& Chandrasegaran, A. L. (2018). Effects of a Mathematics Cognitive Acceleration Program on student achievement and motivation. International Journal of Science and Mathematics Education, 16(1), 183-202. doi: https://doi.org/10.1007/s10763-016-9763-5

Gopnik, A. (2012). Scientific thinking in young children: Theoretical advances, empirical research, and policy implications. Science, 337(6102), 1623-1627. doi: https://doi.org/10.1126/science.1223416

Inhelder, B., \& Piaget, jean. (1958). The growth of logical thinking from childhood to adolescence: An Essay on ... - Bärbel Inhelder, Jean Piaget - Google Books. London and New York: Routledge and Kegan Paul Ltd. Retrieved from https://books.google.co.id/books?id=39cdDv2-PZkC\&printsec=frontcover\#v=onepa ge\&q\&f=false

Mccormack, L., Finlayson, O. E., \& Mccloughlin, T. J. J. (2009). The development and evaluation of second level lessons, central to the Cognitive Acceleration through Science Education methodology The development and evaluation of second level lessons, central to the Cognitive Acceleration through Science Education met. In Thomas McCloughlin. Retrieved from https://www.researchgate.net/publi cation/272789503_The_development_and_evaluation_of_second_level_lessons_central_to_the_Cognit ive_Acceleration_through_Science_Education_methodology

Milar, S., Venville, G., \& Oliver, M. (2014). Cognitive Acceleration. In Encyclopedia of Science Education (pp. 1-4). Retrieved from https://research-repository.uwa.edu.au/en/publications/cognitive-acceleration

Oroujlou, N., \& Vahedi, M. (2011). Motivation, attitude, and language learning. Procedia - Social and Behavioral Sciences, 29, 994-1000. doi: https://doi.org/10.1016/j.sbspro.2011.11.333

Osagie, R. O., \& Alutu, A. N. (2016). Factors affecting gender equity in the choice of science and technology careers among secondary school students in Edo State, Nigeria. International Education Studies, 9(10), 
231-236. doi: https://doi.org/10.5539/ies.v9n10p231

Schunk, D. H., \& Zimmerman, B. J. (2008). Motivation and self-regulated learning: Theory, research, and applications. New York: Taylor \& Francis Group, LLC. Retrieved from https://books.google.co.id/books?i d=MDQLfOg0jXOC\&pg=PR4\&lpg=PR4\&dq=\%22Motivation:+An+essential+dimension+of+self-regulated +learning\%22\&source=bl\&ots=CE4uK7nMAo\&sig=ACfU3U1Xg4yvbx2GuFzpB9ra682bPYRmeQ\&hl=en \&sa=X\&ved=2ahUKEwiOnK_Jro7kAhVEQHOKHYFYCP04ChDoATAD

Shaikh, Z., \& Khoja, S. (2012). Role of teacher in personal learning environments. Digital Education Review, 21(June), 23-32. Retrieved from https://files.eric.ed.gov/fulltext/EJ972714.pdf

Velayutham, S., Aldridge, J., \& Fraser, B. (2011). Development and validation of an instrument to measure students' motivation and self-regulation in science learning. International Journal of Science Education, 33(15), 2159-2179. doi: https://doi.org/10.1080/09500693.2010.541529

Venville, G., \& Oliver, M. (2015). The impact of a cognitive acceleration programme in science on students in an academically selective high school. Thinking Skills and Creativity, 15, 48-60. doi: https://doi.org/10. 1016/J.TSC.2014.11.004

Wolters, C. A. (1999). Motivational regulation and their use of learning strategies, effort and classroom performance. Learning and Individual Differences, 3(3), 281-299. doi: https://doi.org/10.1016/S10416080(99)80004-1

Wyk, M. M. V. (2017). The effects of the STAD-Cooperative Learning Method on student achievement, attitude and motivation in Economics education, 8923. doi: https://doi.org/10.1080/09718923.2012.11 893104 